\title{
Szemaglutid és a kardiovaszkuláris kockázat - a SUSTAIN-6 vizsgálat eredményei
}

\author{
Jermendy György dr.
}

\begin{abstract}
Összefoglalás
A szemaglutid a GLP-1-receptoragonista készitmények legújabb tagja, amely 2019 elején hazánkban is elérhetóvé válik. Hetente egyszer adandó injektábilis készitmény, amelyet a 2-es tipusú diabetesben szenvedök kezelésére regisztráltak. Alapvetö tulajdonságait, hatásosságát és biztonságosságát a SUSTAIN elnevezésü (Semaglutide Unabated Sustainability in Treatment of Type 2 Diabetes) III. fázisú vizsgálatsorozatban tesztelték. A SUSTAIN-6 vizsgálatot hatósági elöirás nyomán a kardiovaszkuláris biztonságosság megitélése érdekében végezték 2-es típusú diabetesben szenvedö olyan betegek körében, akiknél kardiovaszkuláris betegség vagy idült vesebetegség ismert/dokumentált volt. A randomizält, kettös vak, placebokontrollos, összesen 109 hétig tartó prospektiv tanulmányban 3297 beteg vett részt, a medián követési idö 2,1 év volt. Az aktiv ágon heti $1 \times 0,5 \mathrm{mg}$, illetve heti $1 \times 1,0 \mathrm{mg}$ szemaglutid szerepelt, az összehasonlitó ágon a betegek placebót kaptak megtartott, standard antidiabetikus kezelés mellett. Elsödleges végpont (kardiovaszkuláris halál, nem végzetes myocardialis infarctus, nem végzetes stroke) a szemaglutidot kapók között 6,6\%-ban, a placebocsoportban 8,9\%-ban fordult elö (esélyhányados: 0,74; 95\%-os megbizhatósági tartomány: 0,58-0,95; $p<0,001$ a non-inferioritást, $p=0,02$ a szuperioritást tesztelve). Szemaglutid (vs. placebo) mellett az új vagy romló nephropathia diabetica relatív kockázata statisztikailag értékelhetöen csökkent, a retinopathia diabetica relativ kockázata szignifikánsan nött. A SUSTAIN-6 vizsgálat igazolta, hogy a szemaglutid (vs. placebo) 2-es típusú diabetesben szenvedö betegek körében kardiovaszkuláris szempontból biztonságosan adható, és ezen túlmenöen alkalmazása elönyösen csökkenti a kardiovaszkuláris kimeneteli eseményeket. Kulcsszavak: 2-es típusú diabetes, antidiabeticum, GLP-1-receptoragonista, szemaglutid, kardiovaszkuláris kockázat
\end{abstract}

\section{Semaglutide and cardiovascular risk - results from the SUSTAIN-6 clinical trial}

Summary: Semaglutide, a new GLP-1 receptor-agonist derivative, has become available in 2019 in Hungary. This injectable, once weekly antidiabetic drug was registered and approved for treating patients with type 2 diabetes. Its efficacy and safety were investigated in the SUSTAIN phase III clinical trials (Semaglutide Unabated Sustainability in Treatment of Type 2 Diabetes). According to the requirements of health authorities, the SUSTAIN-6 trial was performed to investigate the cardiovascular safety of semaglutide. In total, 3297 patients with type 2 diabetes and established cardiovascular disease or chronic kidney disease were enrolled and semaglutide $(0.5 \mathrm{mg}$ or $1.0 \mathrm{mg}$ once weekly) with corresponding placebo were used. The median follow-up of this randomized, double blind, placebo-controlled, 109-week-long trial was 2.1 years. The primary outcome (composite of cardiovascular death, non-fatal myocardial infarction, non-fatal stroke) occurred in $6.6 \%$ of patients with semaglutide vs. $8.9 \%$ of patients with placebo (hazard ratio: $0.74 ; 95 \%$ confidence interval: $0.58-0.95 ; p<0.001$ for non-inferiority, $p=0.02$ for superiority). Rates of new or worsening nephropathy were significantly lower in the semaglutide group, whereas rates of retinopathy complications were significantly higher. The SUSTAIN-6 clinical trial documented not only non-inferiority but cardiovascular superiority of semaglutide over placebo in patients with type 2 diabetes at high cardiovascular risk.

Keywords: type 2 diabetes, antidiabetic drugs, GLP-1 receptor-agonist, semaglutide, cardiovascular risk 
Rövidítések

ADA: Amerikai Diabetes Társaság (American Diabetes Association); Cl: megbízhatósági tartomány (confidence interval); DPP-4-: dipeptidilpeptidáz-4; EASD: Európai Diabetes Társaság (European Association for the Study of Diabetes); eGFR: becsült glomeruláris filtrációs ráta (estimated glomerular filtration rate); GLP-1: glukagonszerü peptid-1; GLP-1-RA: GLP-1-receptoragonista; HR: kockázati esély (hazard risk); MACE: nagy kardiovaszkuláris esemény (major adverse cardiovascular event); NYHA: New York Heart Association; SGLT-2: nátrium-glukóz kotranszporter-2 (sodium-glucose cotransporter-2)

A szemaglutid a GLP-1-RA készítmények legújabb tagja, amely 2019 elején hazánkban is elérhetővé válik. Hetente egyszer adandó injektábilis készítmény, amelyet a 2-es típusú diabetesben szenvedők kezelésére regisztráltak. Alapvető tulajdonságait, hatásosságát és biztonságosságát a SUSTAIN elnevezésű (Semaglutide Unabated Sustainability in Treatment of Type 2 Diabetes) III. fázisú vizsgálatsorozatban tesztelték. Ennek a vizsgálatsorozatnak egyik tagjaként a SUSTAIN-6 vizsgálatot a kardiovaszkuláris biztonságosság megítélése érdekében végezték.

Már megszokhattuk 2008 óta, hogy a piacra kerülő új, innovatív antidiabeticumok kardiovaszkuláris biztonságosságának vizsgálatát hatósági előírás nyomán szervezik meg a fejlesztést végző cégek. A kardiovaszkuláris biztonságosság azért került az érdeklődés homlokterébe, mert 2007-ben, az éveken keresztül alkalmazott rosiglitazonnal kapcsolatban egy metaanalízis eredményei a myocardialis infarctus kockázatnövekedését dokumentálták. Bár az eredmények helyességét sokan vitatták, a hatóság jelentős szigorítást vezetett be. ${ }^{1}$ Egyrészt a rosiglitazont Európában kivonták a forgalomból, az Egyesült Államokban pedig jelentősen megszigorították alkalmazását. Másrészt 2008-tól kezdve kötelezővé tették azt, hogy a forgalmazni kívánt, vagy a közelmúltban forgalmazott antidiabeticumokkal randomizált, kontrollált klinikai tanulmányokat kell végezni a kardiovaszkuláris kockázat megítélése érdekében. Egy adott készítmény csak akkor kerülhetett a piacra, vagy maradhatott forgalomban, ha a vizsgálatok legalább a placebóval szembeni egyenértékűséget (non-inferioritást) igazolták. Egyes készítményeknél azonban a non-inferioritáson túlmenően előnyt (szuperioritást) is dokumentáltak. Jellemző módon a kardiovaszkuláris klinikai kimenetel alakulását tesztelő vizsgálatok IIIb fázisú tanulmányként, már befogadott, regisztrált készítményekkel zajlottak. Valamennyi tanulmányban 2-es típusú diabetesben szenvedő, fokozott kardiovaszkuláris kockázatú betegek szerepeltek, a vizsgálati készítményt a betegek a zajló antidiabetikus terápia megtartása mellett (add on) kapták. A GLP-1-RA készítményeket illetően így zajlott az ELIXA (lixiszenatid vs. placebo), a LEADER (liraglutid vs. placebo), az EXSCEL (heti egyszeri exanatid vs. placebo), a HARMONY (albiglutid vs. placebo) és a REWIND (dulaglutid vs. placebo) vizsgálat., 2,3,45 Valamennyi tanulmány eredményeit publikálták, kivéve a REWIND vizsgálatot, amelyről 2019 elején csak sajtóközlemény áll rendelkezésre. A SUSTAIN-6 vizsgálat ${ }^{6}$ az előzőekben említett tanulmányok sorába tartozik, de kivitelezésének voltak olyan sajátosságai is, amelyek eltértek a korábbiakétól.

\section{SUSTAIN-6 vizsgálat}

\section{Vizsgálati cél}

A szerzők még a fejlesztés stádiumában (regisztráció előtt), IIIa fázisú vizsgálatban kívántak adatokat gyüjteni a heti egyszeri szemaglutid kardiovaszkuláris biztonságosságáról non-inferioritási (placebóval egyenértékűséget igazoló) tanulmány keretén belül. A hatósági előírás szerint fejlesztés alatt lévő készítménynél ez akkor teljesül, ha az esélyhányados 95\%-os megbízhatósági tartományának felső értéke 1,8 alatt marad.

\section{Vizsgálat módja}

A véletlen besorolás elvét követő, kettős vak, placebokontrollos vizsgálat 20 ország 230 centrumában zajlott. A betegek 1:1:1:1 arányban négy ágra kerültek:

1. szemaglutid heti $1 \times 0,5 \mathrm{mg}$;

2. megfelelő placebo; 


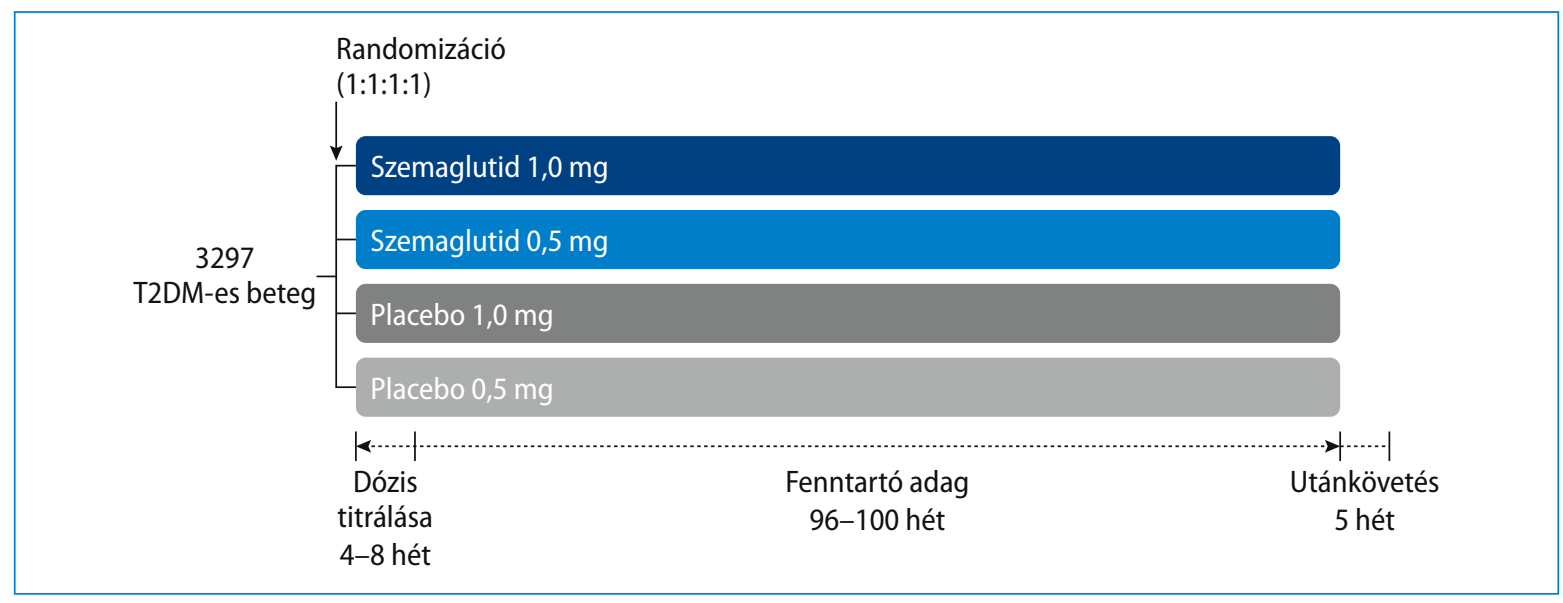

\section{1. ábra. A SUSTAIN-6 vizsgálat felépítése}

3. szemaglutid heti $1 \times 1,0 \mathrm{mg}$;

4. megfelelő placebo.

A vizsgálat tartama összesen 109 hét volt (104 hét vizsgálat, 5 hét utánkövetés) (1. ábra). A vizsgálati készítmény dózisát a betegek előre lefektetett módszer szerint növelték: szemaglutid kezdő dózis: heti $0,25 \mathrm{mg} 4$ hétig, amely után a dózist tovább emelték heti $0,5 \mathrm{mg}$-ra, ezt követően tértek át a fenntartó dózisra (ami vagy heti $1 \times 0,5 \mathrm{mg}$, vagy heti egyszer $1,0 \mathrm{mg}$ volt). A fenntartó dózist a vizsgálat során nem lehetett változtatni. A készítményt a betegek subcutan kapták, a zajló antidiabetikus terápia megtartása mellett. Ez utóbbi az adott országban érvényes alkalmazási előírás szerinti, standard terápiát jelentette. Ellenőrző vizitekre negyedévenként került sor. A vizsgálatot a Novo Nordisk szponzorálta.

\section{Vizsgált betegcsoport}

A tanulmányba 2-es típusú diabetesben szenvedő betegeket vontak be (életkor: $\geq 50$ év, $\mathrm{HbA}_{1 \mathrm{c}}$ : $\geq 7,0 \%$ ), a korábbi kezelés lehetett csak életmódterápia, vagy gyógyszeres antidiabetikus kezelés: maximum két orális szer \pm bázis- vagy premix inzulin. Beválasztási feltétel volt a kardiovaszkuláris, cerebrovaszkuláris vagy perifériás érbetegség, szívelégtelenség (NYHA II-III. stádium) vagy idült vesebetegség (3. stádium) jelenléte. A vizsgálatba bekerülhettek 60 év feletti betegek akkor is, ha esetükben legalább egy kardiovaszkuláris kockázati tényező igazolható volt. A legfontosabb kizárási kritériumok az alábbiak voltak: heveny coronaria- vagy cerebrovaszkuláris esemény 90 nappal a beválasztás előtt, tervbe vett revaszkularizáció bármely érterületen, tartós dialízis, korábbi DPP-4-gátló vagy más GLP-1-RA készítmény adása 30 nappal a beválasztás előtt.

A betegek bevonása 2013. február és december között történt, a vizsgálat utolsó vizitjére 2016. március 15-én került sor. A követés medián tartama 2,1 év volt. A betegek 99,6\%-ában tudtak adatokat gyüjteni a vitális paraméterekről. A szemaglutid $0,5 \mathrm{mg}$ ágon 826 beteg, a szemaglutid 1,0 mg ágon 822 beteg, a megfelelő placebo ágon 824 és 825 beteg szerepelt. A teljes vizsgálati kohorszt $(n=3297)$ tekintve a betegek életkora 64,6 év, diabetestartamuk 13,9 év, a kiindulási $\mathrm{HbA}_{1 \mathrm{c}}$-érték $8,7 \%$ volt, a betegek 83,0\%-ában kardiovaszkuláris betegség ismert vagy kimutatott volt. A betegek 93,5\%-a antihypertensiv, 76,5\%-uk lipidcsökkentő és 76,3\%-uk thrombocytaaggregáció-gátló kezelésben részesült.

\section{Kimeneteli végpontok}

Elsődleges összevont végpontként a kardiovaszkuláris halál, a nem végzetes myocardialis infarctus és a nem végzetes stroke ( 3 pontos MACE) első megjelenését értékelték. Másodlagos végpontként több eseményt analizáltak: kiterjesztett összevont kardiovaszkuláris végpont (3 pontos MACE 
+ revaszkularizáció, szívelégtelenség vagy instabil angina miatti hospitalizáció), össz-halálozás, a 3 pontos MACE összetevői külön-külön, retinopathia-események, új vagy romló nephropathia. A kimeneteli eseményeket független bizottság minősítette. Több biztonságossági paramétert regisztráltak: hypoglykaemia-események alakulása, daganatos betegségek, pancreatitis előfordulása.

A kardiovaszkuláris események alakulásának bemutatásánál a szerzők a két szemaglutid- és a két placebocsoportot összevontan értékelték. A glykaemiás hatékonyság, a testsúly és a biztonságossági paraméterek közlésénél a négy vizsgálati csoport külön-külön szerepelt.

\section{Eredmények}

Elsődleges végpont ( 3 pontos MACE) a szemaglutidot kapók között 6,6\%-ban, a placebocsoportban 8,9\%-ban fordult elő (HR: 0,74; 95\%-os CI:
0,58-0,95; $\mathrm{p}<0,001$ a non-inferioritást, $\mathrm{p}=0,02$ a szuperioritást tesztelve) (2. ábra). A nem végzetes myocardialis infarctus numerikusan előnyösebben alakult az aktív ágon, de a különbség nem bizonyult szignifikánsnak (HR: 0,74; 95\%-os CI: $0,51-1,08 ; p=0,12)$. Nem végzetes stroke statisztikailag értékelhetően ritkábban fordult elő szemaglutid vs. placebo mellett (HR: 0,61; 95\%-os CI: 0,38-0,99; $\mathrm{p}=0,04)$. A kardiovaszkuláris halálozás tekintetében a két csoport között nem mutatkozott értékelhető különbség (HR: 0,98; 95\%-os CI: 0,65-1,48; $\mathrm{p}=0,92)$ (3. ábra). A kardiovaszkuláris kockázatcsökkenés között nem volt érdemi eltérés akkor, ha a szemaglutidot kapó két csoportot (dózis heti $1 \times 0,5 \mathrm{mg}$ és heti $1,0 \mathrm{mg}$ ) külön értékelték.

A $\mathrm{HbA}_{1 \mathrm{c}}$-változás (a 104. héten talált értékből kivonva a kiindulási értéket) az alábbiak szerint alakult: a $0,5 \mathrm{mg}$ szemaglutid csoportban $-1,1 \%$, szemaglutid 1,0 mg csoportban $-1,4 \%$, mindkét placebocsoportban $-0,4 \%(\mathrm{p}<0,001)$.

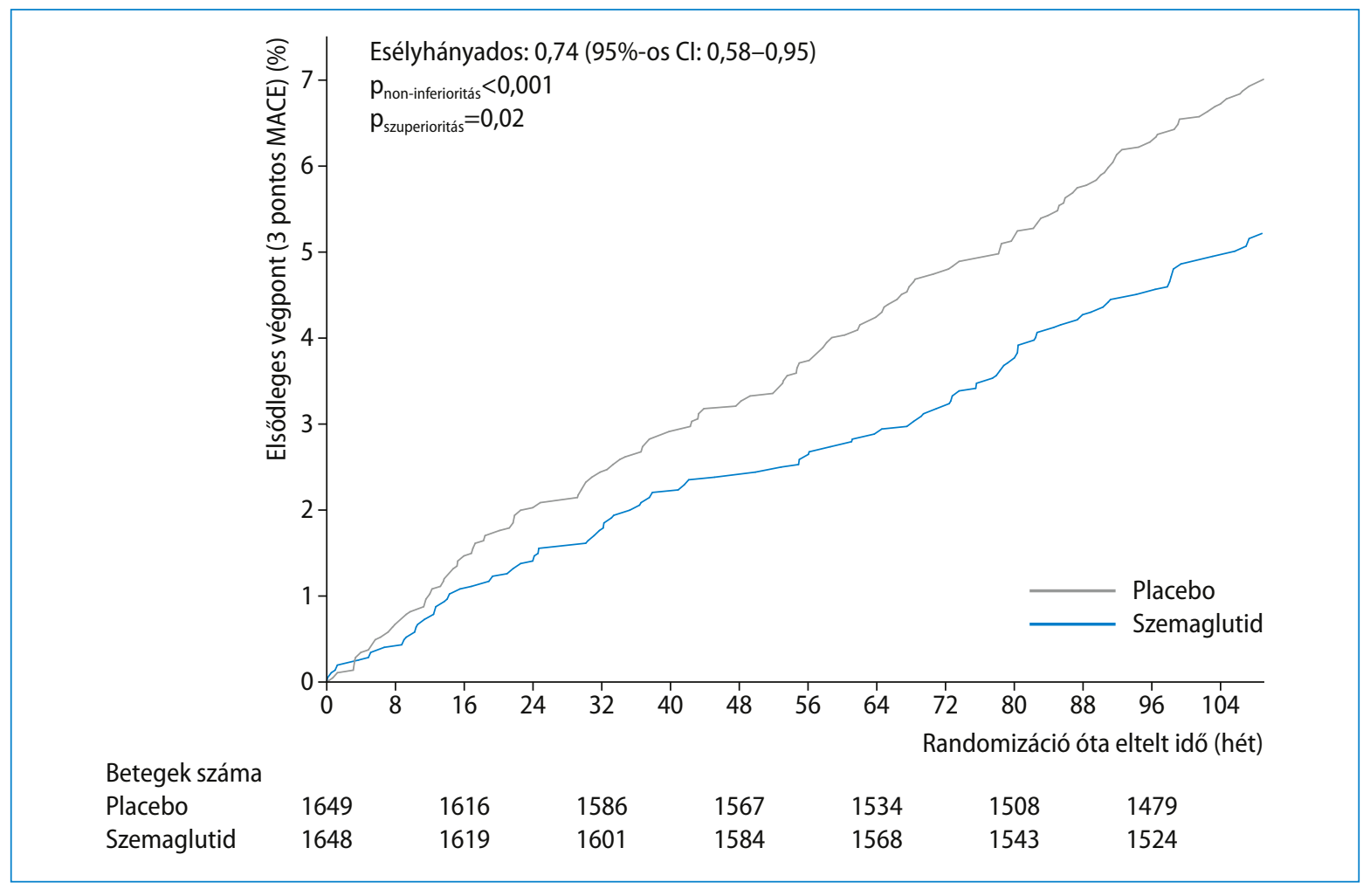

2. ábra. A SUSTAIN-6 vizsgálat kardiovaszkuláris kimeneteli eseményei - Elsődleges végpont (3 pontos MACE) (Forrás: Marso SP, et al.: N Engl J Med 2016; 375: 1834-1844. A kiadó engedélyével.) 


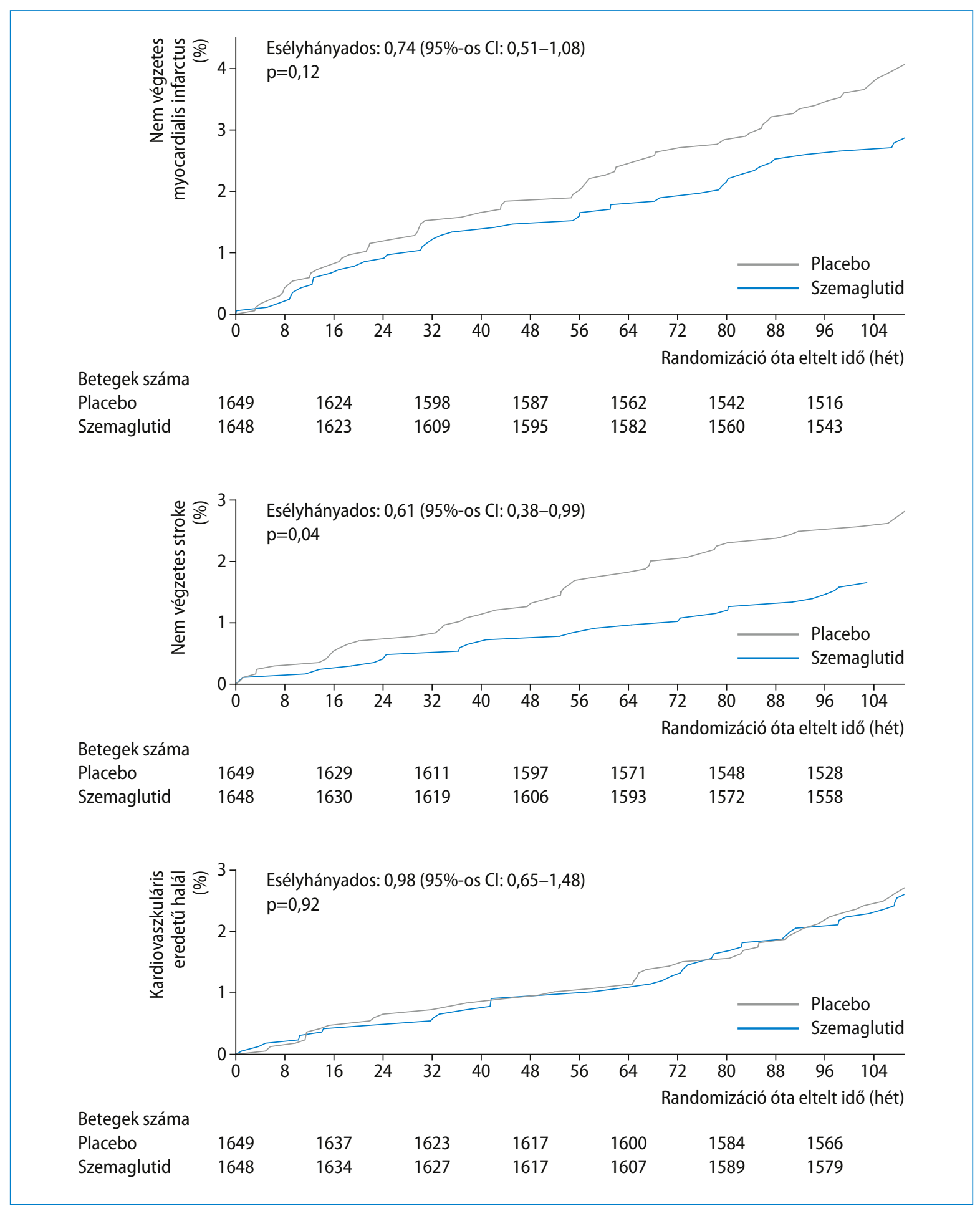

3. ábra. A SUSTAIN-6 vizsgálat kardiovaszkuláris kimeneteli eseményei (Forrás: Marso SP, et al.: N Engl J Med 2016; 375: 1834-1844. A kiadó engedélyével) 
A testsúlyváltozás (a 104. héten talált értékből kivonva a kiindulási értéket) az alábbiak szerint alakult: a $0,5 \mathrm{mg}$ szemaglutid csoportban $-3,6 \mathrm{~kg}$, a szemaglutid $1,0 \mathrm{mg}$ csoportban $-4,9 \mathrm{~kg}$, a placebocsoportban $-0,7 \mathrm{~kg}$ és $-0,5 \mathrm{~kg}(\mathrm{p}<0,001)$.

Diabeteses retinopathiás szövődmények gyakrabban fordultak elő szemaglitud vs. placebo mellett (HR: 1,76; 95\%-os CI: 1,11-2,78; $\mathrm{p}=0,02$ ). Új vagy romló nephropathiás szövődmények értékelhetően ritkábban fordultak elő szemaglutid vs. placebo mellett (HR: 0,64; 95\%-os CI: 0,46-0,88; $\mathrm{p}=0,005)$.

A systolés vérnyomás csökkenése nagyobb volt szemaglutid vs. placebo mellett (placebóval korrigált változás: szemaglutid $0,5 \mathrm{mg}:-1,3 \mathrm{Hgmm}$; szemaglutid 1,0 mg: $-2,6 \mathrm{Hgmm} ; \mathrm{p}<0,001)$. A diastolés vérnyomásértékek alakulása terén nem volt értékelhető különbség a csoportok között. A szívfrekvencia növekedése nagyobb volt szemaglutid vs. placebo mellett (placebóval korrigált változás: szemaglutid $0,5 \mathrm{mg}$ : $2,0 / \mathrm{min}$, szemaglutid $1,0 \mathrm{mg}$ : 2,5/min; $\mathrm{p}<0,001$ ).

Gastrointestinalis mellékhatások gyakrabban fordultak elő szemaglutid vs. placebo mellett. Ezek a mellékhatások enyhék voltak és a követés első 30 hetében jelentkeztek. Akut pancreatitis az aktív ágon 9 betegnél, a placebocsoportban 12 betegnél fordult elő. Pancreascarcinoma az aktív ágon 1 betegnél, a placebocsoportban 4 betegnél fordult elő. A hypoglykaemia-események alakulása terén a csoportok között nem mutatkozott értékelhető különbség.

\section{Következtetések}

A vizsgálat eredményei szerint az elsődleges célkitűzés teljesült, a szemaglutid placebóval szembeni non-inferioritása igazolható volt. A 3 pontos
MACE esélyhányadosának alakulása azonban a törzskönyvezés előtti kardiovaszkuláris kimeneteli vizsgálathoz szükséges kisebb statisztikai erő ellenére igen jó volt. A 95\%-os megbízhatósági tartomány felső határértéke ugyanis bőven 1,8 alatt (ez volt az előírt kritérium), sőt 1,0 alatt maradt, ami azt jelenti, hogy a 26\%-os relatívkockázat-csökkenés (HR: 0,74; 95\%-os CI: 0,58-0,95) a biztonságosságon túlmutató előnyt is igazolt. Az adatok jelzik, hogy az összevont kardiovaszkuláris előny hátterében elsősorban a nem végzetes stroke jelentős és a nem végzetes myocardialis infarctus szerényebb csökkenése állt, a kardiovaszkuláris halálozás érdemben nem változott.

A microangopathiás szövődmények alakulása terén a szemaglutid veseprotekcióra utaló tulajdonságát lehetett megfigyelni. A retinopathiás szövődmények ugyanakkor szemaglutid mellett gyarapodtak, ami kicsit váratlan volt. Későbbi (post hoc) analízisek ugyanakkor rámutattak arra, hogy ezek az események a korábban inzulinnal kezelt és már retinopathiában szenvedő betegek körében voltak megfigyelhetők akkor, ha a szemaglutid a kiindulási $\mathrm{HbA}_{1 c}$-érték viszonylag gyors csökkenését eredményezte. ${ }^{7}$ A diabetológiai irodalomban már évtizedekkel ezelőtt megfigyelt, később a DCCT-ben is regisztrált fenoménről van szó, a túl gyors vércukorcsökkenés a retinopathiás szövődmények átmeneti romlását okozhatja, s erre a körülményre a betegek kezelésvezetésekor figyelemmel kell lenni. ${ }^{8,9}$ A szemaglutid alkalmazási előírása erre a körülményre külön kitér. ${ }^{10}$

Klinikailag mindenképpen figyelemre méltó a glykaemiás kontroll szemaglutid mellett észlelt javulása, a testsúlycsökkenés és a systolés vérnyomás előnyös alakulása. Minden bizonnyal ezeknek a tényezőknek is szerepe lehetett a kardiovaszkuláris szövődmények előnyös alakulásában. Figyelemre

\section{1. táblázat. A GLP-1-RA készítményekkel végzett, publikált tanulmányok alapvető jellegzetességei}

\begin{tabular}{|c|c|c|c|c|}
\hline Vizsgálat & Betegszám & Készítmény & Követési idő & $\begin{array}{c}\text { Ismert/dokumentált } \\
\text { kardiovaszkuláris betegség }\end{array}$ \\
\hline ELIXA & 6068 & Lixiszenatid & 2,1 év & $100 \%$ \\
\hline LEADER & 9340 & Liraglutid & 3,8 év & $81 \%$ \\
\hline SUSTAIN-6 & 3297 & Szemaglutid & 2,1 év & $83 \%$ \\
\hline EXSCEL & 14752 & Exenatid & 3,2 év & $73 \%$ \\
\hline HARMONY & 9463 & Albiglutid & 1,6 év & $100 \%$ \\
\hline
\end{tabular}


méltó adat azonban az, hogy állatkísérletekben a szemaglutid csökkentette az atherosclerosis kialakulását, megelőzte az aortaplakk progresszióját és a plakkon belül csökkentette a gyulladást. ${ }^{11}$

A GLP-1-RA készítményekkel végzett kardiovaszkuláris biztonságossági vizsgálatok közül a SUSTAIN-6 tanulmányon túl a LEADER (liraglutid) és a HARMONY (albiglutid) eredményei igazoltak előnyös tulajdonságot, a REWIND (dulaglutid) is előnnyel zárult, de ennek részletes adatait még nem publikálták. A tanulmányok öszszehasonlítása természetesen nehéz, ${ }^{12}$ hiszen más volt a betegcsoport és a követési idő (1. táblázat). Mindazonáltal az ADA/EASD legújabb konszenzusriportjában leírtakat meg kell szívlelnünk: a kardiovaszkuláris megbetegedés, az idült vesebetegség és a szívelégtelenség jelenléte 2-es típusú diabetesben komolyan mérlegelendő körülmény. ${ }^{13}$ A dokumentált előnnyel rendelkező GLP-1-RA készítményeket elsősorban akkor érdemes választani a metformin-terápia első kiegészítéseként, ha ismert/kimutatott atherosclerotikus eredetű megbetegedés is jelen van. A szemaglutid előnyét érdemes akkor is kiaknázni, ha az adott betegnél a testsúly gyarapodása komoly mérlegelési körülmény. Renális protekció biztosítása érdekében is alternatív választási lehetőség a bizonyított előnynyel rendelkező GLP-1-RA, főleg akkor, ha SGLT2-gátló készítmény a vesefunkció károsodása (eGFR $<60 \mathrm{ml} / \mathrm{min} / 1,73 \mathrm{~m}^{2}$ ) miatt nem kezdhető.

A SUSTAIN-6 vizsgálatnak a fentieken túlmenően még egy érdekes hozadéka is lett. Feltehetően a vizsgálat kivitelezésének körülményei (IIIa fázisú vizsgálat, regisztráció előtt, viszonylag alacsonyabb betegszámmal, nem túl hosszú követési idővel) és jó eredményei alátámasztották azoknak a szakértőknek a javaslatait, akik a kardiovaszkuláris kimeneteli vizsgálatok eddigi gyakorlatának megváltoztatása mellett kezdtek el érvelni. ${ }^{14}$ Részben anyagi, részben időbeni megtakarítás céljából a SUSTAIN-6 vizsgálathoz hasonló jellegű tanulmányok szervezése ugyanis feltehetően előnyösebb lenne. A szakmai közvélemény kíváncsian várja, hogy ezen a téren lesz-e változás a közeljövőben.
Irodalom

1. Jermendy Gy: Miért vált napjainkban központi kérdéssé az antidiabetikumok kardiovaszkuláris biztonságossága? Metabolizmus 2015; 13: 367-372.

2. Pfeffer MA, Claggett B, Diaz R, Dickstein K, Gerstein HC, Køber LV, et al; ELIXA Investigators: Lixisenatide in patients with type 2 diabetes and acute coronary syndrome. N Engl J Med 2015; 373: 2247-2257. doi:10.1056/NEJMoa1509225

3. Holman RR, Bethel MA, Mentz RJ, Thompson VP, Lokhhnygina Y, Buse JB, et al.: Effects of once-weekly exenatide on cardiovascular outcomes in type 2 diabetes. N EnglJ Med 2017; 377: 1228-1239. doi:10.1056/NEJMoa1612917

4. Marso SP, Daniels GH, Brown-Frandsen K, Kristensen P, Mann, JFE, Nauck MA, et al.: Liraglutide and cardiovascular outcomes in type 2 diabetes. $\mathrm{N}$ Engl I Med 2016; 375: 311-322. doi:10.1056/NEJMoa1603827

5. Jendle J, Grunberger G, Blevins T, Giorgino F, Hietzpas RT, Boitros FT: Efficacy and safety of dulaglutide in the treatment of type 2 diabetes: a comprehensive review of the dulaglutide clinical data focusing on the AWARD phase 3 clinical trial program. Diabetes/Metab Res Rev 2016; 32: 776-790. doi:10.1002/dmrr.2810

6. Marso SP, Bain SC, Consoli A, Eliaschewitz FG, Jódar E, Leiter LA, et al.: Semaglutide and cardiovascular outcomes in patients with type 2 diabetes. N EnglJ Med 2016; 375: 1834-1844. doi:10.1056/NEJMoa1607141

7. Vilsbøll T, Bain SC, Leiter LA, Lingvay I, Matthews D, Simó R, et al.: Semaglutide, reduction in glycated haemoglobin and the risk of diabetic retinopathy. Diabetes Obes Metab 2018; 20: 889-897. doi:10.1111/dom.13172

8. Dahl--ørgensen K, Brinchmann-Hansen 0 , Hanssen KF, Sandvik L, Aagenaes 0 : Rapid tightening of blood glucose control leads to transient deterioration of retinopathy in insulin dependent diabetes mellitus: the 0slo study. Br Med J (Clin Res Ed) 1985; 290: 811-815. doi:10.1136/bmj.290.6471.811

9. Diabetes Control and Complications Trial Research Group: The effect of intensive treatment of diabetes on the development and progression of long-term complications in insulin-dependent diabetes mellitus. N Engl J Med 1993; 329: 977-986. doi:10.1056/NEJM199309303291401

10. Ozempic alkalmazási elöirás

11. Rakipovski G, Rolin B, Nøhr J, Klewe I, Frederiksen KS, Augustin R, et al.: The GLP-1 analogs liraglutide and semaglutide reduce atherosclerosis in ApoE- 1 and LDLr-I- mice by a mechanism that includes inflammatory pathways. JACC Basic TransI Sci 2018; 3: 844-857. doi:10.1016/j.jacbts.2018.09.004

12. Home P: Cardiovascular outcome trials of glucose-lowering medications: an update. Diabetologia 2019; 62:357-369. doi:10.1007/s00125-018-4801-1

13. Davies MJ, D'Alessio DA, Fradkin J, Kernan WN, Mathieu C, Mingrone G, et al.: Management of hyperglycaemia in type 2 diabetes, 2018. A consensus report by the American Diabetes Association (ADA) and the European Association for the Study of Diabetes (EASD). Diabetes Care 2018; 41: 2669-2701. doi:10.1007/s00125-018-4729-5

14. Tucker ME: FDA Panel: Keep CV Outcomes Trials for Diabetes but Tweak Them. Medscape 2018. 0ct. 26. https://www.medscape.com/viewarticle/904011 [letöltve: 2019. 02.28.]

Közlésre érkezett: 2019. március 1.

Közlésre elfogadva: 2019. március 6.

A szerzö levelezési címe:

\section{Dr. Jermendy György}

Bajcsy-Zsilinszky Kórház és Rendelőintézet

1106 Budapest, Maglódi út 89-91.

E-mail: gyjermendy@gmail.com 